J. Mark K.H. Wierda MD PhD, Anton M. Beaufort MD, Ursula W. Kleef BSc, Nicky J. Smeulers MD, Sandor Agoston MD PhD

\title{
Preliminary investi- gations of the clinical pharmacology of three short-acting non-depolarizing neuro- muscular blocking agents, Org 9453, Org 9489 and Org 9487
}

Three muscle relaxants, Org 9453, Org 9489 and Org 9487, short-acting in animals, were investigated to establish their profiles in humans. Potency, time course of action, and pharmacokinetic behaviour were studied in 90 healthy patients during fentanyl/halothane $/ \mathrm{N}_{2} \mathrm{O}$ anaesthesia. Neuromuscular function was monitored mechanomyographically. Plasma and urine concentrations (three patients per compound) were measured by $H P L C$, and these data were analyzed by iterative linear least square regression analysis. The $E D_{90}$ values for Org 9453, Org 9489 and Org 9487 were $1.4,0.45$ and $1.15 \mathrm{mg} \cdot \mathrm{kg}^{-1}$ respectively. The onset times of Org $9453\left(1.5 \mathrm{mg} \cdot \mathrm{kg}^{-1}, 1.1 \times E D_{90}\right)$. Org $9489\left(0.9 \mathrm{mg} \cdot \mathrm{kg}^{-1}, 2 \times E D_{90}\right)$ and Org 9487 (1.5 $\left.\mathrm{mg} \cdot \mathrm{kg}^{-1}, 1.3 \times E D_{90}\right)$ were $1.2,1.6$ and $1.5 \mathrm{~min}$, and the durations until $25 \%$ twitch recovery were $8.6,22.0$ and $8.9 \mathrm{~min}$, respectively. Clearances of these doses were 6.9, 5.8, and 11.1 $\mathrm{ml} \cdot \mathrm{kg}^{-1} \cdot \mathrm{min}^{-1}$, and mean residence times 26,79 , and 41 min, respectively. Mean renal excretion (parent compound and metabolites) within $24 \mathrm{hr}$ amounted to 5, 11.3 and $12.2 \%$ respectively. No side effects other than a moderate short-lasting

\section{Key words}

NEUROMUSCULAR RELAXANTS: Org 9453, Org 9489, Org 9487.

From the Research Group for Experimental Anesthesiology and Clinical Pharmacology, Department of Anesthesiology, University Hospital of Groningen, PB 30001, 9700 RB Groningen, the Netherlands.

Address correspondence to: Dr. J. Mark K.H. Wierda,

Department of Anesthesiology, University Hospital,

Oostersingel 59, 9713 EZ Groningen, the Netherlands.

Supported by Organon Teknika International, Tumhout, Belgium.

Accepted for publication 6th November, 1993. decrease of blood pressure and a concomittant increase in heart rate were noted. It is concluded that Org 9453 and Org 9487 are short-acting muscle relaxants in humans.

Trois myorelaxants à courte durée d'action chez l'animal, l'Org 9453, l'Org 9489 et l'Org 9487 sont étudiés pour déterminer leurs caractéristiques chez l'homme. La puissance, le décours temporel de leur activité et leur comportement pharmacologique sont étudiés chez 90 adultes bien portants pendant une anesthésie constituée de fentanyl/halothane/protoxyde d'azote. La fonction neuromusculaire est monitorisée par électromyographie. Les concentrations urinaires et plasmatiques (trois patients par produit) sont titrées par chromatographie en phase liquide et ces données analysées par régression linéaire itérative multiple. Les valeurs de l'ED 90 pour l'Org 9453, l'Org 9489 et l'Org 9487 sont de 1,4, 0.45 et $1,15 \mathrm{mg} \cdot \mathrm{kg}^{-1}$ respectivement. Le début d'action de l'Org $9453\left(1,5 \mathrm{mg} \cdot \mathrm{kg}^{-1}, 1,1 \times E D_{90}\right)$ l'Org $9489\left(0,9 \mathrm{mg} \cdot \mathrm{kg}^{-1}, 2 \times E D_{90}\right)$ et l'Org $9487(1,5$ $\left.\mathrm{mg} \cdot \mathrm{kg}^{-1}, 1,3 \times E D_{90}\right)$ sont de $1,2,1,6$ et $1,5 \mathrm{~min}$ respectivement. A ces doses, la clairance est de $6,9,5,8$ et $11,1 \mathrm{ml} \cdot \mathrm{kg}^{-1}$ respectivement et les temps de séjour moyen 26,79 et $41 \mathrm{~min}$, respectivement. En-deça de $24 \mathrm{~h}$, l'excrétion rénale moyenne (produit et métabolites) se situe à 5, 11,3 et 12,2\% respectivement. On ne note pas d'effets secondaires à l'exception d'une baisse modérée transitoire de la pression artérielle accompagnée d'une augmentation de la fréquence cardiaque. En conclusion. l'Org 9453 et l'Org 9487 sont des myorelaxants à courte durée d'action.

The introduction of succinylcholine into anaesthetic practice in 1951 provided the anaesthetist with a muscle relaxant characterized by a rapid onset and an ultra-short duration of action. The use of succinylcholine, however, 
sometimes results in serious and even life-threatening complications, ${ }^{1,2}$ mainly due to its depolarizing mode of action. Despite considerable efforts over more than $\mathbf{4 0}$ $\mathrm{yr}$, its time course of action is still unequalled by that of more recently developed muscle relaxants.

The search for a non-depolarizing neuromuscular blocking agent to replace succinylcholine has resulted in the synthesis and testing of numerous compounds. In particular, compounds with a low potency have a faster onset and shorter duration of action in cats. ${ }^{3}$ Onset potency data from cat experiments (Organon Laboratories, Scotland) obtained with compounds, which were also evaluated in man, are depicted in Figure 1.

Modifications in the cyclo-amino structure of the substituents to the androstene skeleton of aminosteroidal neuromuscular blocking agents resulted in the development of Org 9426 and Org 9273. Both agents showed rapid development of neuromuscular block both in animals ${ }^{4-6}$ and in humans, ${ }^{7-12}$ although the duration of action of these agents is not different from the intermediate duration of action produced by vecuronium bromide.

Modifications in the 17-ester group of these compounds resulted in the development of Org 9453 (17 $\beta$-butyrate analogue of vecuronium bromide), Org 9489 (17 $\beta$ propionate analogue of vecuronium bromide) and Org 9487 (16N-allyl, 173-propionate analogue of vecuronium bromide (Figure 2).

In animal studies these compounds were short-acting with a rapid development of neuromuscular block and a short duration of action. We studied the potency, time course of action, and the pharmacokinetic behaviour of Org 9453, Org 9489 and Org 9487 in humans.

\section{Methods}

After approval from the Medical Ethics Committee of the University Hospital Groningen and written informed consent from each patient were obtained, 90 patients, ASA physical status 1 or 2 and aged between 18 and $65 \mathrm{yr}$, were studied. No patient received medication known to interact with neuromuscular blocking agents. None suffered from renal disease, neuromuscular disorders or hepatic failure. Each drug was studied in 30 patients and each patient received only one of the compounds under investigation. The three compounds were investigated successively using a flexible protocol with respect to doses applied, in order to obtain sufficient data to make first estimates for each compound of the $\mathrm{ED}_{90}$ dose and the dose necessary for intubation. Potency, timecourse, and pharmacokinetic data should be considered as preliminary and descriptive. They vary to some extent among compounds and therefore do not allow statistical comparisons.
MIN.

(LOG SCALE)

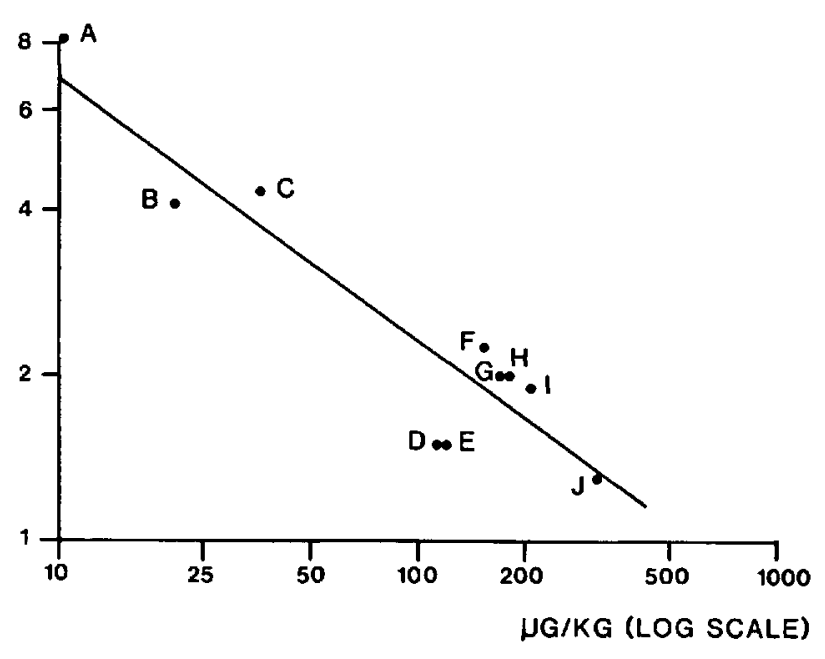

FIGURE 1 The relationship between effective dose $\left(\mu \mathrm{g} \cdot \mathrm{kg}^{-1}\right)$ and onset time (min) for ten aminosteroidal neuromuscular blocking drugs in the anaesthetized cat (log-scale). The effective dose (abscissa) is the mean dose to produce $50 \%$ twitch depression $(0.1 \mathrm{~Hz})$ of the tibialis anterior muscle. The onset time (ordinate) is the mean time from injection to the maximum effect after a dose producing a 90-99\% twitch depression. $(\mathrm{A}=$ pipecuronium, $\mathrm{B}=$ pancuronium, $\mathrm{C}=$ vecuronium, $D=\operatorname{Org} 9273, E=\operatorname{Org} 9616, F=\operatorname{Org} 9489, G=\operatorname{Org}$ 9426 (rocuronium), $\mathrm{H}=\operatorname{Org} 9453, \mathrm{I}=$ Org 9487, J = Org 7617). Data from Dr. A. Muir, Organon Laboratories, Newhouse, Scotland).

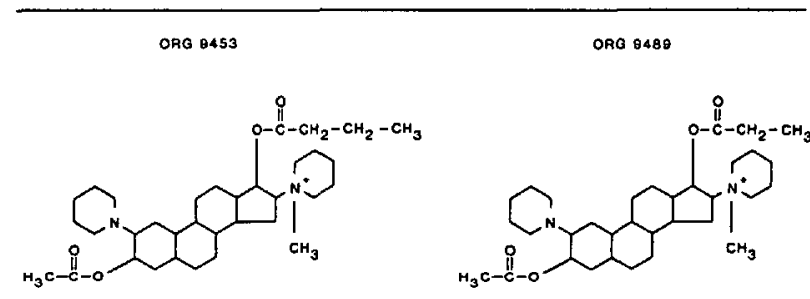

ORQ 9487

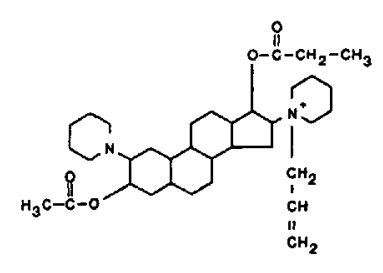

FIGURE 2 Org 9453 (17 $\beta$-butyrate analogue of vecuronium bromide), Org 9489 (17ß-propionate analogue of vecuronium bromide) and Org 9487 (16N-allyl, 17ß-propionate analogue of vecuronium bromide). 


\section{Anaesthetic technique}

Premedication consisted of 7.5-15 mg midazolam po, approximately one hour before the expected start of anaesthesia. After connection to the monitoring equipment (ECG, non-invasive blood pressure monitor, pulse oximeter, neuromuscular function monitor), the patient breathed oxygen for two minutes followed by induction of anaesthesia with fentanyl 3-6 $\mu \mathrm{g} \cdot \mathrm{kg}^{-1}$ and thiopentone $4-6 \mathrm{mg} \cdot \mathrm{kg}^{-1} i v$. As soon as the eyelid reflex disappeared, assisted ventilation via a facemask was started with halothane up to an inspiratory concentration of $1 \%$ in a gas mixture of $65 \%$ nitrous oxide in oxygen. After tracheal intubation, anaesthesia was maintained with the same anaesthetic gas mixture (expiratory halothane concentration approximately $0.5 \mathrm{MAC}$.). If required, additional doses of fentanyl $\left(0.5-1.5 \mu \mathrm{g} \cdot \mathrm{kg}^{-1} i v\right)$ were administered. The blood pressure was measured at short intervals and heart rate and oxygen saturation were measured continuously. The PETCO , controlled during mask ventilation by sampling the exhaled gases via a small canula positioned in the hypopharynx, was kept between 4.0 and $4.6 \mathrm{kPa}$.

\section{Pharmacodynamic measurements}

Neuromuscular function was monitored mechanomyographically (Relaxometer ${ }^{13}$ ). The ulnar nerve was stimulated at the wrist at a frequency of $0.1 \mathrm{~Hz}$. Train-of-four stimuli (TOF) were administered at $25 \%, 75 \%$ and $90 \%$ twitch height recovery and thereafter at intervals until clinically sufficient recovery was obtained (TOF $=70 \%$ ). The contraction of the adductor pollicis muscle was measured isometrically with a force transducer. The lag time (time from end of injection until first twitch depression), the onset time (time from end injection until maximum block), the maximum block, the clinical duration (time from end of injection until $25 \%$ recovery of twitch height), the total duration (time from end of injection until $90 \%$ recovery of twitch height), the recovery index (time elapsing between $25 \%$ and $75 \%$ recovery of twitch height) and the duration until clinically sufficient recovery (time from end of injection until recovery of the train-of-four response to $70 \%$ ) were measured.

In general, for each compound, in the first ten patients the trachea was intubated after maximum effect was obtained. The remaining 20 patients were divided into two subgroups; in ten patients the tracheas were intubated one minute following administration of the relaxant under investigation and in ten patients intubation was five minutes later to obtain data on intubating conditions and haemodynamic effects respectively.

Heart rate and blood pressure were registered throughout the experiment, particularly just before and every minute for ten minutes after administration of the drug under investigation.

\section{Determination of potency}

All doses of neuromuscular blocking agents were injected over 5-10 sec into a fast running infusion, in a peripheral arm vein. An initial estimate of the potency for each compounds, i.e., the dose producing $90 \%$ neuromuscular block $\left(\mathrm{ED}_{90}\right)$, was obtained in the first six patients using a cumulative dose technique. These patients received up to five successive predetermined doses, administered at intervals of two minutes. Administration was stopped as soon as twitch depression of $\geq 90 \%$ had been obtained. The initial dose was $0.05 \mathrm{mg} \cdot \mathrm{kg}^{-1}$ in the first three patients. Incremental doses (maximum of four) were 0.05 , 0.1 , and $0.15 \mathrm{mg} \cdot \mathrm{kg}^{-1}$ in the first, second and third patients respectively. In the next three patients the initial dose and the incremental doses were chosen in accordance with the results obtained in the previous three experiments. An initial estimate of the $\mathrm{ED}_{90}$ dose was then made and verified in a further 5-10 patients. The remaining 14-19 patients received a dose that was expected to produce a block of the adductor pollicis muscle of $\geq 75 \%$ one minute following its administration. Based on experience acquired from previous studies with steroidal muscle relaxants this degree of adductor pollicis block was assumed to coincide with satisfactory intubating conditions. In the case of a short onset time of a submaximal blocking dose $\left(\leq 120 \mathrm{sec}\right.$.), 1-1.3 times the $\mathrm{ED}_{90}$ dose was expected to be an adequate dose to reach the required degree of block at one minute, whereas in the case of a longer onset time of a submaximal blocking dose, twice the $\mathrm{ED}_{90}$ dose was expected to be necessary to reach the required degree of block ( $\geq 75 \%$ ) within one minute. Finally at the end of the study the $\mathrm{ED}_{90}$ values were recalculated using linear regression analysis on $\log$-logit transformed dose-response data obtained in patients following single administrations of doses equal or less than 1.3 times the initially estimated $\mathrm{ED}_{90}$ dose. Patients with complete block have been included in this regression analysis (arbitrary logit value 2).

\section{Pharmacokinetics}

The pharmacokinetic behaviour of an intubating dose was studied in nine patients, i.e., three patients per compound. Blood samples were collected from a peripheral arterial line. A blank sample was taken before administration of the muscle relaxant and at $1,2,4,6,9,12,15,25,40$, $60,75,90,120,180,240,360$, and $480 \mathrm{~min}$ after administration of the drug under investigation. Additional samples were taken at $25 \%$ and $75 \%$ recovery of the single-twitch response. To prevent spontaneous deacetylation of the muscle relaxant, blood samples were acidified immediately after collection with $1 \mathrm{M} \mathrm{NaH}_{2} \mathrm{PO}_{4}$ in a ratio of $4: 1$. To prevent haemolysis the samples were kept at room temperature. Within four hours the plasma 
was separated and kept frozen at $-18^{\circ} \mathrm{C}$ until analysis.

Urine was collected in fractions via a catheter and representative samples of these fractions were taken before administration of the muscle relaxant and 2, 4, 6, 9, 12, 18 and $24 \mathrm{hr}$ thereafter. To prevent spontaneous deacetylation of the muscle relaxant the sampling bag was acidified before each sampling period with $1 \mathrm{ml} \mathrm{I} \mathrm{M}$ $\mathrm{NaH}_{2} \mathrm{PO}_{4}$.

The concentrations of the compounds were determined by means of the HPLC method described for rocuronium bromide, ${ }^{14}$ which was modified and validated for Org 9453, Org 9489, Org 9487 and their putative derivatives. After a liquid/liquid extraction from the biological materials, the compounds and their putative metabolites were separated by HPLC followed by post-column ionpair extraction and fluorimetric detection. The method showed a linear relationship between the logarithm of the drug amount and the logarithm of the response ratio (peak height Org 9487/peak height of the internal standard) in a range of at least $10-1000 \mathrm{ng}$ in the prepared sample. The intra-day precision of the determinations of the parent compounds is determined in plasma (range: $10-1000 \mathrm{ng}, n=5,5-1000 \mu \mathrm{l}$ plasma can be processed) and in urine (range: $10-1200 \mathrm{ng}, n=5,5-1000 \mu$ l urine can be processed). The intra-day precision amounts in plasma to $8.4-8.1 \%$ for Org $9453,18.2-7.1 \%$ for Org $9489,9.4-9.4 \%$ for Org 9487 and in urine to $11.0-8.9 \%$ for Org 9453, 4.9-3.4\% for Org 9489 and finally to $10.9-7.2 \%$ for Org 9487 . The accuracy of the determinations of the parent compounds in plasma and urine are listed in Table I.

Both the intra-day precision and accuracy of the putative derivatives do not essentially differ from those of the parent compounds. In plasma the lower limit of quantification, defined as the lowest concentration which can be determined with a precision and accuracy better than $15 \%$, is $10 \mathrm{ng} \cdot \mathrm{ml}^{-1}$ for Org 9453 , Org 9487, 17-OH Org 9487 and 3,17 di-OH Org $9487,20 \mathrm{ng} \cdot \mathrm{ml}^{-1}$ for 3-OH 9487 and $25 \mathrm{ng} \cdot \mathrm{ml}^{-1}$ for 3-OH Org 9453, Org 9489 and 3-OH Org 9489. In urine the lower limit of quantification is $10 \mathrm{ng} \cdot \mathrm{ml}^{-1}$ for Org 9453, 3-OH Org 9453, Org 9489, 3-OH Org 9489, Org 9487, 3-OH Org 9487 and $50 \mathrm{ng} \cdot \mathrm{ml}^{-1}$ for Org 17-OH Org 9487 and 3,17 di-OH Org 9487.

Pharmacokinetic analysis was based on iterative linear least-square regression analysis by the computer program MULTIFIT, using different minimizing algorithms (Marquardt, Simplex, CFT3). ${ }^{15}$ Initial estimates are obtained automatically by a stripping procedure (ESTRIP). MULTIFIT provides all relevant pharmacokinetic variables which are calculated using standard equations. ${ }^{16}$
TABLE I The accuracy of the determinations, expressed as the percentage of the added amount, of Org 9453, Org 9489 and Org 9487 in plasma and in urine (mean (CV))

\begin{tabular}{lrrrr}
\hline Compound & $\begin{array}{c}\text { Concentr. } \\
\left.(n g \cdot m)^{-1}\right)\end{array}$ & $n$ & $\begin{array}{c}\text { Found } \\
(\%)\end{array}$ & $\begin{array}{c}C V \\
(\%)\end{array}$ \\
\hline Plasma & & & & \\
Org 9453 & 10 & 4 & 90.0 & 12.8 \\
& 20,000 & 4 & 100.2 & 9.0 \\
Org 9489 & 10 & 4 & 86.0 & 1.3 \\
& 20,000 & 4 & 107.0 & 2.2 \\
Org 9487 & 50 & 5 & 97.8 & 9.8 \\
& 250 & 4 & 95.6 & 2.4 \\
& 5000 & 4 & 96.6 & 2.4 \\
& 9901 & 2 & 97.0 & 7.2 \\
Urine & & & & \\
Org 9453 & 10 & 3 & 105.6 & 9.9 \\
& 20,000 & 3 & 98.2 & 11.3 \\
Org 9489 & 200 & 4 & 105.0 & 1.5 \\
& 12,000 & 4 & 110.0 & 0.8 \\
Org 9487 & 100 & 4 & 95.8 & 5.3 \\
& 1000 & 4 & 102.0 & 7.3 \\
& 50,000 & 4 & 105.4 & 3.2 \\
\hline
\end{tabular}

\section{Statistical analysis}

Plasma concentration data were fitted to a two and three exponential equation and the appropriate equation for each patient was determined by F-test. Results are presented as mean values and coefficients of variation in brackets, unless stated otherwise.

\section{Results}

\section{Potency and time course of action}

Based on the cumulative dose-response data obtained from six patients in each group, the $\mathrm{ED}_{90}$ was initially estimated to be $1.3,0.4$ and $1.0 \mathrm{mg} \cdot \mathrm{kg}^{-1}$ for Org 9453 , Org 9489 and Org 9487 respectively. Following completion of the study $\mathrm{ED}_{90}$ values were recalculated (vide supra). The final estimates for the $\mathrm{ED}_{90}$ dose amounted to $1.4,0.45$ and $1.15 \mathrm{mg} \cdot \mathrm{kg}^{-1}$ for Org 9453 , Org 9489 and Org 9487 respectively. The magnitude and time course of the neuromuscular blocking effects of different doses of Org 9453, Org 9489 and Org 9487 are presented in Table II. Intubation at one minute after administration of the relaxant could be accomplished easily in all patients showing a neuromuscular block at the adductor pollicis muscle $\geq 75 \%$.

Cardiovascular effects were moderate for all three compounds, showing a mean decrease of blood pressure $\leq 10 \%$ with a concomittant mean increase in heart rate $\leq 20 \%$ after doses between one and two times the $\mathrm{ED}_{90}$ dose. Side effects indicative for histamine release, such 
TABLE II Magnitude and time course of the neuromuscular blocking effects of Org 9453, Org 9489 and Org 9487 in anaesthetized patients $($ mean $(\mathrm{SD}))$

\begin{tabular}{|c|c|c|c|c|c|c|c|c|c|}
\hline $\begin{array}{l}\text { Dose } \\
\left(m g \cdot k g^{-l}\right)\end{array}$ & $n$ & $\begin{array}{l}\text { Lag time } \\
\text { (sec) }\end{array}$ & $\begin{array}{l}\text { Block } \\
60 \mathrm{sec} \\
(\%)\end{array}$ & $\begin{array}{l}\text { Max. } \\
\text { block } \\
\text { (\%) }\end{array}$ & $\begin{array}{l}\text { Onset } \\
\text { time } \\
\text { (sec) }\end{array}$ & $\begin{array}{l}\mathrm{Dur}_{25} \\
(\text { min) }\end{array}$ & $\begin{array}{l}\text { Dur }_{90} \\
\text { (min) }\end{array}$ & $\begin{array}{l}\text { R.I. } \\
(\min )\end{array}$ & $\begin{array}{l}T^{T O F_{70}} \\
(\mathrm{~min})\end{array}$ \\
\hline \multicolumn{10}{|l|}{ Org 9453} \\
\hline 1.3 & 7 & $\begin{array}{l}19 \\
(8)\end{array}$ & $\begin{array}{l}75 \\
(29)\end{array}$ & $\begin{array}{l}95 \\
(9)\end{array}$ & $\begin{array}{l}103 \\
(37)\end{array}$ & $\begin{array}{r}7.5 \\
(2.5)\end{array}$ & $\begin{array}{l}16.0 \\
(4.7)\end{array}$ & $\begin{array}{r}5.8 \\
(1.6)\end{array}$ & $\begin{array}{l}21.4 \\
(3.1)\end{array}$ \\
\hline 1.4 & 7 & $\begin{array}{l}15 \\
(7)\end{array}$ & $\begin{array}{l}85 \\
(6)\end{array}$ & $\begin{array}{l}97 \\
(2)\end{array}$ & $\begin{array}{l}105 \\
(33)\end{array}$ & $\begin{array}{c}7.1 \\
(2.0)\end{array}$ & $\begin{array}{l}15.7 \\
(5.7)\end{array}$ & $\begin{array}{c}6.1 \\
(2.0)\end{array}$ & $\begin{array}{l}20.4 \\
(6.6)\end{array}$ \\
\hline 1.5 & 4 & $\begin{array}{l}16 \\
(5)\end{array}$ & $\begin{array}{l}92 \\
(11)\end{array}$ & $\begin{array}{l}96 \\
(7)\end{array}$ & $\begin{array}{r}69 \\
(27)\end{array}$ & $\begin{array}{r}8.6 \\
(1.8)\end{array}$ & $\begin{array}{l}16.3 \\
(1.7)\end{array}$ & $\begin{array}{r}5.9 \\
(0.6)\end{array}$ & $\begin{array}{l}23.5 \\
(2.5)\end{array}$ \\
\hline \multicolumn{10}{|l|}{ Org 9489} \\
\hline 0.4 & 12 & $\begin{array}{l}34 \\
(9)\end{array}$ & $\begin{array}{l}54 \\
(19)\end{array}$ & $\begin{array}{r}86 \\
(12)\end{array}$ & $\begin{array}{l}188 \\
(34)\end{array}$ & $\begin{array}{r}7.9 \\
(2.5)\end{array}$ & $\begin{array}{l}17.5 \\
(5.1)\end{array}$ & $\begin{array}{c}7.2 \\
(2.1)\end{array}$ & $\begin{array}{l}23.0 \\
(5.8)\end{array}$ \\
\hline 0.5 & 7 & $\begin{array}{l}29 \\
(6)\end{array}$ & $\begin{array}{l}71 \\
\text { (11) }\end{array}$ & $\begin{array}{l}96 \\
(3)\end{array}$ & $\begin{array}{l}156 \\
(29)\end{array}$ & $\begin{array}{l}10.4 \\
(1.0)\end{array}$ & $\begin{array}{l}19.0 \\
(3.4)\end{array}$ & $\begin{array}{r}5.9 \\
(1.4)\end{array}$ & $\begin{array}{l}24.6 \\
(3.2)\end{array}$ \\
\hline 0.9 & 5 & $\begin{array}{l}24 \\
(8)\end{array}$ & $\begin{array}{l}96 \\
(40)\end{array}$ & $\begin{array}{l}100 \\
(0)\end{array}$ & $\begin{array}{r}96 \\
(40)\end{array}$ & $\begin{array}{l}22.0 \\
(4.8)\end{array}$ & $\begin{array}{l}41.9 \\
(14.5)\end{array}$ & $\begin{array}{l}12.6 \\
(5.8)\end{array}$ & $\begin{array}{l}52.8 \\
(14.2)\end{array}$ \\
\hline Org 9487 & & & & & & & & & \\
\hline 1.0 & 10 & $\begin{array}{l}29 \\
(3)\end{array}$ & $\begin{array}{l}68 \\
(20)\end{array}$ & $\begin{array}{r}84 \\
(14)\end{array}$ & $\begin{array}{l}126 \\
(25)\end{array}$ & $\begin{array}{r}5.6 \\
(0.7)\end{array}$ & $\begin{array}{l}10.9 \\
(2.4)\end{array}$ & $\begin{array}{r}4.6 \\
(0.4)\end{array}$ & $\begin{array}{l}15.3 \\
(2.5)\end{array}$ \\
\hline 1.5 & 14 & $\begin{array}{l}26 \\
(5)\end{array}$ & $\begin{array}{l}91 \\
(11)\end{array}$ & $\begin{array}{l}100 \\
(1)\end{array}$ & $\begin{array}{r}88 \\
(20)\end{array}$ & $\begin{array}{r}8.9 \\
(2.0)\end{array}$ & $\begin{array}{l}17.9 \\
(7.1)\end{array}$ & $\begin{array}{r}6.1 \\
(3.0)\end{array}$ & $\begin{array}{l}23.6 \\
(6.4)\end{array}$ \\
\hline
\end{tabular}

as flushing, hypotension, or bronchospasm, were not noted.

\section{Pharmacokinetics}

The pharmacokinetic variables of Org 9453, Org 9489 and Org 9487 are listed in Table III. For comparison, data of Org 9426 (rocuronium) obtained in a previous study " are also presented. For all compounds the plasma concentration decay was described best by a triexponential equation. The 3-desacetyl metabolite of Org 9453 could be demonstrated in plasma between one and four hours following administration of the parent compound, although only in limited concentrations, i.e., $<50$ $\mu \mathrm{g} \cdot \mathrm{L}^{-1}$.

The urinary excreted fraction of the administered dose was small, i.e., 5.0\% (1.6) (mean (sd), parent compound and putative metabolites). In two patients small amounts of the 3-desacetyl metabolite could be shown in the urine (1.1 and $0.3 \%$ ). The excretion period was limited to the first six hours of the measuring period of $24 \mathrm{hr}$ (Figure 3).

The 3-desacetyl metabolite of Org 9489 could be demonstrated in plasma over the whole measuring period in a ratio of 10:1 (parent compound:metabolite) in the beginning to $1: 10$ in the end of the sampling period.

The urinary excreted fraction of the administered dose over $24 \mathrm{hr}$ was $11.3 \%$ (4.7) (mean (sd), parent compound and putative metabolites). The excretion occurred mainly in the first six hours. Only the 3-desacetyl metabolite was recovered from the urine (Figure 3).

The 3-desacetyl metabolite of Org 9487 could be demonstrated in plasma over the whole measuring period with concentrations varying from 10:1 (parent compound:metabolite) in the beginning to $1: 10$ in the end of the sampling period.

The urinary excreted fraction of the administered dose was $12.2 \%$ (4.2) (mean (sd), parent compound and putative metabolites). Metabolism seems to be restricted largely to desacetylation on the 3-position, since only tiny amounts of the 3,17-didesacetyl metabolite could be recovered from the urine.

\section{Discussion}

Org 9453 and Org 9487 are non-depolarizing neuromuscular blocking agents characterized by a low potency, a rapid rate of block development, and a short time course of neuromuscular blocking action compared with currently available non-depolarizing neuromuscular blocking agents.

The results of this study confirm the empirical relationship between potency and onset time of neuromuscular blocking agents in cats, shown by Bowman $e t$ al. ${ }^{3}$ for a series of steroidal compounds and confirmed in man by Kopman, ${ }^{17}$ using three clinically available but structurally unrelated neuromuscular blocking agents. Inially, Bowman explained his findings with the "Law of 
TABLE III Pharmacokinetic variables (mean (CV)) of Org $9453\left(1.3 \mathrm{mg} \cdot \mathrm{kg}^{-1}, n=3\right)$, Org 9489

$\left(0.9 \mathrm{mg} \cdot \mathrm{kg}^{-1}, n=3\right)$ and Org $9487\left(1.5 \mathrm{mg} \cdot \mathrm{kg}^{-1}, n=3\right)$ Compared with those of Org 9426 (rocuronium, $1 \mathrm{mg} \cdot \mathrm{kg}^{-1}, n=10$ )

\begin{tabular}{llcccc}
\hline Variables & Units & 9453 & 9489 & 9487 & $9426^{*}$ \\
\hline $\mathrm{P}$ & $\mathrm{mg} \cdot \mathrm{L}^{-1}$ & 18.8 & 7.3 & 13.1 & 17.5 \\
& & $(17)$ & $(7)$ & $(27)$ & $(45)$ \\
$\mathrm{A}$ & $\mathrm{mg} \cdot \mathrm{L}^{-1}$ & 2.0 & 2.2 & 2.4 & 4.7 \\
& & $(81)$ & $(38)$ & $(54)$ & $(15)$ \\
$\mathrm{B}$ & $\mathrm{mg} \cdot \mathrm{L}^{-1}$ & 0.1 & 0.1 & 0.3 & 0.5 \\
& & $(107)$ & $(85)$ & $(59)$ & $(96)$ \\
$\mathrm{T}_{1 / 2 \mathrm{n}}$ & $\mathrm{min}$ & 4.1 & 4.4 & 2.8 & 1.8 \\
& & $(20)$ & $(52)$ & $(54)$ & $(33)$ \\
$\mathrm{T}_{1 / 2 \alpha}$ & $\mathrm{min}$ & 23 & 29 & 14.5 & 19 \\
& & $(53)$ & $(37)$ & $(49)$ & $(34)$ \\
$\mathrm{T}_{1 / 2 \beta}$ & $\mathrm{min}$ & 83 & 237 & 88 & 131 \\
& & $(59)$ & $(57)$ & $(19)$ & $(62)$ \\
$\mathrm{V}_{\mathrm{c}}$ & $\mathrm{ml} \cdot \mathrm{kg}^{-1}$ & 62 & 94 & 95 & 45 \\
& & $(24)$ & $(12)$ & $(21)$ & $(29)$ \\
$\mathrm{V}_{\mathrm{ss}}$ & $\mathrm{ml} \cdot \mathrm{kg}^{-1}$ & 179 & 459 & 457 & 267 \\
$\mathrm{Cl}$ & $(10)$ & $(55)$ & $(28)$ & $(56)$ \\
& $\mathrm{ml} \cdot \mathrm{kg}^{-1} \cdot \mathrm{min}^{-1}$ & 6.9 & 5.8 & 11.1 & 4.0 \\
$\mathrm{MRT}$ & $\mathrm{min}$ & $(21)$ & $(24)$ & $(10)$ & $(24)$ \\
& & 26 & 79 & 41 & 67 \\
& & $(16)$ & $(30)$ & $(27)$ & $(31)$ \\
\hline
\end{tabular}

*Wienda et al. 1991."

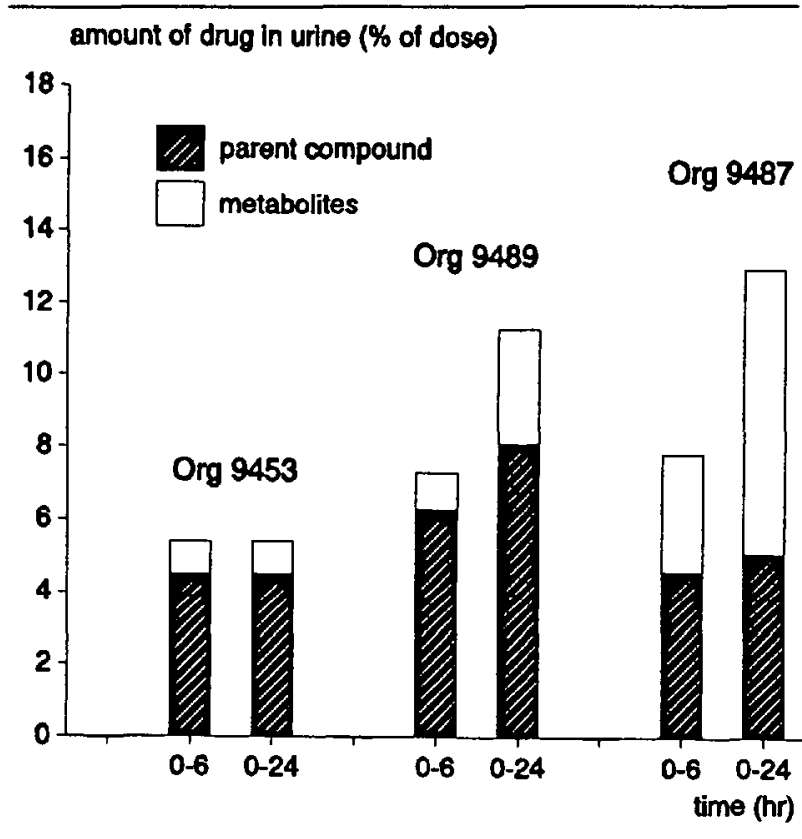

FIGURE 3 The amount of Org 9453, Org 9489, Org 9487 and their putative metabolites in urine after 6 and $24 \mathrm{hr}$, as percentages of the administered bolus-doses $\left(1.3 \mathrm{mg} \cdot \mathrm{kg}^{-1} \mathrm{Org} 9453,0.9 \mathrm{mg} \cdot \mathrm{kg}^{-1} \mathrm{Org}\right.$ 9489 and $1.5 \mathrm{mg} \cdot \mathrm{kg}^{-1} \mathrm{Org} 9487$ ).

Mass Action," suggesting that an increase in concentration-gradient between plasma and neuromuscular junction, which is characteristic for compounds with a low potency, accelerates the onset of neuromuscular blockade. However, assuming linear pharmacokinetics, a decrease in intrinsic potency should only increase the dose necessary to obtain a certain degree of block without altering the onset time. Donati et al. ${ }^{18}$ explained this empirical relationship by differences in the degree of binding of agents in the effect compartment. The more potent the neuromuscular blocking agent, the smaller its fraction unbound, and consequently, the longer it will take until equilibration has been completed. Others explained this relationship using the concept of buffered diffusion. ${ }^{19}$ The relationship, however, may also be explained by differences in pharmacokinetic behaviour between compounds. A more rapid initial decay of the plasma concentration coincides with a more rapid equilibration between plasma and biophase, with subsequent shortening of the onset time. ${ }^{20}$ Another interesting mechanism that could accelerate the rate of equilibration may be in part responsible for the extremely short onset times $(\leq 120 \mathrm{~s})$ of these new steroidal compounds. In vitro, i.e., in the rat aortic strip model, these agents possess calcium channel blocking properties in concentrations that may occur immediately after an intubating dose. ${ }^{20}$ This may result in a shortlasting blockade of calcium channels, which in turn may increase the nutritional muscle blood flow, ${ }^{21,22}$ thereby enhancing the rate of equilibration between plasma and biophase. Other potential consequences of temporary calcium channel block may be involved as well in the rate of block development, such as diminished release of acetylcholine from the nerve terminal (less competition) and 
TABLE IV Pharmacodynamic variables (mean (SD)) of estimated intubating doses of Org 9453, Org 9489 and Org 9487 compared with those of succinylcholine and of Org 9426 (rocuronium)

\begin{tabular}{|c|c|c|c|c|c|c|}
\hline $\begin{array}{l}\text { Dose } \\
\left(m g \cdot k g^{-1}\right)\end{array}$ & $n$ & $\begin{array}{l}E D_{90^{-}} \\
\text {equivalent }\end{array}$ & $\begin{array}{l}\text { Onset time } \\
\text { (min) }\end{array}$ & $\begin{array}{l}\mathrm{Dur}_{25} \\
\text { (min) }\end{array}$ & $\begin{array}{l}\text { Dur }_{90} \\
\text { (min) }\end{array}$ & $\begin{array}{l}\text { R.I. } \\
(\min )\end{array}$ \\
\hline \multicolumn{7}{|c|}{ Succinylcholine* (after $10 \mathrm{mg}$ gallamine) } \\
\hline 1.5 & 20 & $>3$ & $\begin{array}{l}1.4 \\
(0.4)\end{array}$ & $\begin{array}{r}5.4 \\
(1.2)\end{array}$ & $\begin{array}{r}7.5 \\
(1.7)\end{array}$ & $\begin{array}{r}1.6 \\
(0.5)\end{array}$ \\
\hline \multicolumn{7}{|l|}{ Org 9453} \\
\hline 1.5 & 4 & 1.1 & $\begin{array}{l}1.2 \\
(0.5)\end{array}$ & $\begin{array}{r}8.6 \\
(1.8)\end{array}$ & $\begin{array}{l}16.3 \\
(1.7)\end{array}$ & $\begin{array}{r}5.9 \\
(0.6)\end{array}$ \\
\hline \multicolumn{7}{|l|}{ Org 9489} \\
\hline 0.9 & 5 & 2 & $\begin{array}{l}1.6 \\
(0.7)\end{array}$ & $\begin{array}{l}22.0 \\
(4.8)\end{array}$ & $\begin{array}{l}41.9 \\
(14.5)\end{array}$ & $\begin{array}{l}12.6 \\
(5.8)\end{array}$ \\
\hline \multicolumn{7}{|l|}{ Org 9487} \\
\hline 1.5 & 14 & 1.3 & $\begin{array}{l}1.5 \\
(0.3)\end{array}$ & $\begin{array}{r}8.9 \\
(2.0)\end{array}$ & $\begin{array}{l}17.9 \\
(7.1)\end{array}$ & $\begin{array}{r}6.1 \\
(3.0)\end{array}$ \\
\hline \multicolumn{7}{|c|}{ Org 9426 (rocuronium) $\dagger$} \\
\hline 0.5 & 11 & 1.7 & $\begin{array}{l}3.4 \\
(1.2)\end{array}$ & $\begin{array}{l}21.2 \\
(5)\end{array}$ & $\begin{array}{l}33.6 \\
(8.5)\end{array}$ & $\begin{array}{r}8.8 \\
(3.1)\end{array}$ \\
\hline
\end{tabular}

*Huizinga et al. 1992.12

†Wierda et al. $1990{ }^{7}$

diminished contractility due to decreased influx of calcium in the muscle fibre (enhanced effect). Comparison of potential intubating doses of these three compounds with those of succinylcholine (ultra-short duration of action) and Org 9426 (rocuronium, intermediate duration of action) characterizes Org 9453 and Org 9487 as shortacting agents, whereas Org 9489 is more like the muscle relaxants with an intermediate duration of action (Table IV).

The decrease in blood pressure following administration of these new compounds is accompanied by an increase in heart rate and is most probably the result of direct vasodilatation. ${ }^{20} \mathrm{~A}$ potential contribution of vagolytic activity, however, cannot be excluded since in the cat (Organon Laboratories, Newhouse) these compounds showed vagal/neuromuscular blocking ratios between those of pancuronium (3) and Org 9426 (rocuronium, 8 ), both compounds which may show slight vagolytic effects in the upper clinical dose range. These limited and short-lasting cardiovascular side effects may not necessarily be unwanted since they may counteract the opioidinduced increased vagal tone and limit the pressure response to tracheal intubation.

Org 9453 and Org 9487 differ from vecuronium ${ }^{23}$ and rocuronium, ${ }^{11}$ both muscle relaxants with an intermediate duration of action, by their relatively high plasma clearances and short mean residence times. Org 9489 resembles, in both pharmacodynamic and pharmacokinetic activity, more the muscle relaxants with an intermediate duration of action.
The rapid occurrence of the 3-desacetyl metabolite of both Org 9487 and Org 9489 suggests a potentially relevant (non-)enzymatic degradation. The influence of the 3-desacetyl metabolite on the time course of blocking effects after an intubating dose will be negligible, since the concentration remains low. Besides, the 3-desacetyl metabolite is expected to be rather impotent, most probably half that of the parent compound (extrapolation from cat data, Organon Laboratories, Newhouse). Since only small amounts of the administered dose have been recovered from the urine, the time course of action of Org 9453 , Org 9489 and Org 9487 may be expected to be almost independent on renal function. This relative independence of renal function has been shown for other monoquaternary steroidal relaxants as well, whereas their bisquaternary, more hydrophilic, relatives have been found to act for far longer in patients suffering from renal insufficiency. ${ }^{22,24}$

\section{Summary}

In humans, Org 9453 and Org 9487 are relatively low potent neuromuscular blocking agents characterized by a rapid onset, a predictable degree of block, and a short duration of action, deserving further clinical evaluation. Since a number of intermediate non-depolarizing agents has been shown to be suitable for maintenance of surgical relaxation, these new compounds should primarily be applied to facilitate tracheal intubation and to produce relaxation for short-lasting interventions such as curettage, fracture manipulation, or electro-convulsive therapy. The 
rapid and complete reversal within 10 minutes, if neostigmine is administered immediately after an intubating dose of Org 9487, is an additional advantage. ${ }^{25}$

\section{Acknowledgements}

Org 9453, Org 9489 and Org 9487 were provided by Organon Teknika International, Turnhout, Belgium. We thank Miss J.W. Anholts, Mr A. van Buiten, and Mr J.R. Roggeveld for their contributions to plasma and urine determinations, and Dr J.H. Proost for providing Multifit.

\section{References}

1 Lee C. Succinylcholine: its past, present and future. In: Katz RL (Ed.). Muscle Relaxants, Seminars in Anesthesia, 1984, 3. 293-302. Orlando: Grune and Stratton.

2 Donati F, Bevan DR. Suxamethonium - current status. In: Norman J (Ed.). Neuromuscular Blockade, Clinics in Anaesthesiology 1985; 3: 371-85. London: Saunders.

3 Bowman WC, Rodger IW, Houston J, Marshall RJ, McIndewar I. Structure:action relationships among some desacetoxy analogues of pancuronium and vecuronium in the anesthetized cat. Anesthesiology 1988; 69: 57-62.

4 Muir AW, Houston J, Green KL, Marshall RJ, Bowman $W C$, Marshall IG. Effects of a new neuromuscular blocking agent (Org 9426) in anaesthetized cats and pigs and in isolated nerve-muscle preparations. Br J Anaesth 1989; 63: 400-10.

5 Agoston S. Pharmacological profile of neuromuscular blocking agents: present and future trends. Acta Anaesthesiol Belg 1988; 39: 235-7.

6 Booij LHDJ. The development of new non-depolarizing neuromuscular blocking agents. Acta Anaesthesiol Scand 1989; 33S: 101-3.

7 Wierda JMKH, De Wit APM, Kuizenga K, Agoston S. Clinical observations on the neuromuscular blocking action of Org 9426, a new steroidal non-depolarizing agent. Br J Anaesth 1990; 64: 521-3.

8 Foldes FF, Nagashima $H$, Nguyen HD, Schiller WS, Mason MM, Ohta $Y$. The neuromuscular effects of Org 9426 in patients receiving balanced anesthesia. Anesthesiology 1991; 75: 191-6.

9 Booij LDHJ, Knape HTA. The neuromuscular blocking effect of Org 9426. Anaesthesia 1991; 46: 341-3.

10 Van den Broek L, Lambalk LM, Richardson FJ, Wierda $J M K H$. Dose-response relation, neuromuscular blocking action, intubation conditions and cardiovascular effects of Org 9273, a new neuromuscular blocking agent. Anesth Analg 1991; 72: 811-6.

11 Wierda JMKH, Kleef UW, Lambalk LM, Kloppenburg $W D$, Agoston $S$. The pharmacodynamics and pharmacokinetics of Org 9426, a new non-depolarizing neuromuscular blocking agent, in patients anaesthetized with nitrous oxide, halothane and fentanyl. Can J Anaesth 1991; 38: 430-5.

12 Huizinga ACT, Vandenbrom RHG, Wierda JMKH, Hommes FDM, Hennis PJ. Intubating conditions and onset of neuromuscular block of rocuronium (Org 9426); a comparison with suxamethonium. Acta Anaesthesiol Scand 1992; 36: 463-8.

13 Rowaan CJ, Vandenbrom RHG, Wierda JMKH. The Relaxometer: a complete and comprehensive computercontrolled neuromuscular transmission measurement system developed for clinical research on muscle relaxants. J Clin Monit 1993; 9: 38-44.

14 Kleef UW, Proost JH, Roggeveld J, Wierda JMKH. Determination of rocuronium and its putative metabolites in body fluids and tissue homogenates. Journal of Chromatography Biomedical Application 1993; 621: 65-76.

15 Press WH, Flannery BP, Teukolsky SA, Vetterling WT. Numerical Recipes. Cambridge: Cambridge University Press, 1986.

16 Wagner JG, Fundamentals of Clinical Pharmacokinetics. Hamilton: Drug Intelligence Publications, 1975.

17 Kopman AF. Pancuronium, gallamine, and d-tubocurarine compared: is speed of onset inversely related to drug potency? Anesthesiology 1989; 70: 915-20.

18 Donati F, Meistelman C. A kinetic-dynamic model to explain the relationship between high potency and slow onset time for neuromuscular blocking drugs. J Pharmacokinet Biopharm 1991; 19: 537-52.

19 Armstrong DL, Lester HA. The kinetics of tubocurarine action and restricted diffusion within the synaptic cleft. J Physiol 1979; 294: 365-86.

20 Wierda JMKH, Proost JH, Muir AW, Marshall RJ. Design of drugs for rapid onset. Anaesthetic Pharmacology Review 1993; 1: 57-68.

21 Hof RP, Hof A, Scholtysik G, Menninger $K$. Effects of the new calcium antagonist PN-200-110 on the myocardium and the regional peripheral circulation in anesthetized cats and dogs. J Cardiovasc Pharmacol 1984; 6: 407-16.

22 Drexler H, Truog AG, Just H, Zelis R. Effects of calciumblockade and converting-enzyme inhibition on regional blood flow in a conscious rat model of heart failure. Klin Wochenschr 1985; 63: 262-7.

23 Sohn YJ, Bencini AF, Scaf AHJ, Kersten UW, Agoston S. Comparative pharmacokinetics and dynamics of vecuronium and pancuronium in anesthetized patients. Anesth Analg 1986; 65: 233-9.

24 Agoston S, Vandenbrom RHG, Wierda JMKH. Clinical pharmacokinetics of neuromuscular blocking drugs. Clin Pharmacokinet 1992; 22: 94-115.

25 Wierda JMKH, van den Broek L, Proost JH, Verbaan $B W$, Hennis PJ. Time course of action and endotracheal intubating conditions of Org 9487, a new short-acting steroidal muscle relaxant; a comparison with succinylcholine. Anesth Analg 1993; 77: 579-84. 